\title{
Acupuncture: an effective tool on procedures of in vitro fertilization?
}

\section{Acupuntura: um auxílio efetivo em procedimentos de fertilização in vitro?}

Bráulio Fernandes de Carvalho ${ }^{1,2}$,Ingridi de Souza Sene ${ }^{3,4}$, Luiz Evaldo de Moura Pádua ${ }^{3}$,Raimundo Gerônimo da Silva Júnior ${ }^{3,4}$,Paula Andrea Sampaio de Vasconcelos ${ }^{5}$,Leonardo Raphael Santos Rodrigues ${ }^{6}$

${ }^{1}$ Tsukuba University, Ibaraki, Japão

2UNINOVAFAPI, Teresina-PI, Brasil

${ }^{3}$ Universidade Federal do Piauí - UFPI, Teresina-PI, Brasil

${ }^{4}$ Laboratório LAPAC-PI, Teresina-PI, Brasil

${ }^{5}$ Universidade Estadual Paulista - UNESP, Botucatu, São Paulo, Brasil

${ }^{6}$ Faculdade Integral Diferencial - FACID, Teresina-PI, Brasil

\begin{abstract}
The purpose of the present study was to evaluate the impact of acupuncture on in vitro fertilization outcomes of patients undergoing acupuncture during embryo transfer. A retrospective study was realized with records of 30 patients undergoing acupuncture and 108 patients not undergoing acupuncture during embryo transfer. The data was compared to verify the differences onto fertilization, embryo cleavage, pregnancy and abortion rate. To the statistical evaluation the X2 Test was performed, set as significant $p<0.05$. There was no statistical significance difference in any feature analyzed among the groups, although the acupuncture group presented higher pregnancy rate and lower abortion rate. Acupuncture did not presented positive or negative statistical relevant effects into the outcomes of in vitro fertilization procedures. Regardless this result, the present study did not exclude the possibility of acupuncture administration as a tool to pain relief during other procedures, as the transvaginal ultrasound-guided oocyte retrieval.
\end{abstract}

Keywords: Acupuncture therapy. Reproductive techniques, assisted. Embryo transfer. Pregnancy. Abortion.

\section{RESUMO}

O objetivo do presente estudo foi avaliar o impacto da acupuntura em tratamentos de fertilização in vitro de pacientes submetidos ao procedimento de acupuntura durante a transferência embrionária. Foi realizado um estudo retrospectivo utilizando dados de 30 pacientes submetidos à acupuntura e de 108 pacientes não submetidos à acupuntura durante a transferência embrionária. Os dados foram comparados para avaliar diferenças nas taxas de fertilização, clivagem, gravidez e aborto. A análise estatística foi realizada pelo teste $\mathrm{X} 2$ com nível de significância estabelecido em $\mathrm{p}<0.05$. Não houve diferença estatística significante em nenhum dos aspectos analisados, apesar de se ter percebido melhores taxas de gravidez e menores taxas de abortos no grupo submetido à acupuntura. A administração de acupuntura não apresentou alterações positivas ou negativas significativas sobre os resultados dos procedimentos de fertilização in vitro. Apesar desse resultado, não se exclui a possibilidade da acupuntura ser utilizada como um auxílio ao alívio da dor em outros procedimentos, como a aspiração folicular por via transvaginal guiada por ultrassonografia.

Palavras-chave: Terapia por acupuntura. Técnicas reprodutivas assistidas.Transferência embrionária. Gravidez. Aborto.

\section{INTRODUCTION}

The positive effect of acupuncture in the treatment of subfertility may be related to the central sympathetic inhibition by the endorphin system, the change in uterine blood flow and motility, and stress reduction (Westergaard et al., 2006).

Acupuncture may regulate the function of the hypothalamic-pituitary-ovarian axis by changing the concentration of central opioids (Ferin \& Wiele, 1984; Petraglia et al., 1987; Chen \& Yu, 1991; Sato et al., 1997; Cho et al., 1998; Kim et al., 2000). Acupuncture might also change the charge and potential of neurons and the concentrations of electrolytes and neuropeptides, such as b-endorphin (Pettie et al., 1998; Ku \& Chang, 2001). The electric stimulation of acupoints is considered to increase the analgesic effect of acupuncture (Gejervall et al., 2005). Electric stimulation involves the biologic activation of endogenous pain inhibition systems by releasing endogenous opioids and oxytocin, which seem to be essential to the induction of functional changes in different organ systems (Andresson \& Lundeberg, 1995; Han, 2003). Both low and high frequency stimulations have been found to induce analgesia, but different types of endorphins are released depending on the stimulation pattern (Tang et al., 1997; White et al., 2000). Moreover, cumulative analgesic effects may be achieved by longer electric stimulation periods (Ghoname et al., 1999).

In addition to conventional body acupuncture, auricular acupuncture is commonly used in patients undergoing in vitro fertilization procedure (IVF) to improve pregnancy outcome and to relieve pain during oocyte retrieval (Westergaard et al., 2006).

Acupuncture has been reported to affect uterine blood flow. This may improve the endometrial environment for embryo implantation or, contrary, create pulsation that might disturb embryo implantation. Stener-Victorin et al. (1996) demonstrated that the mean pulsatility index of uterine vessels was significantly reduced shortly after electroacupuncture given twice a week for eight times to subfertile women. Moreover, acupuncture over the acupoint LI4 was reported to inhibit uterine motility (Kim et al., 2000). High-frequency uterine contractions on the day of embryo transfer may reduce the pregnancy rate of IVF treatment, possibly by expelling embryos out of the uterine cavity (Fanchin et al., 1998).

Acupuncture has both physiologic and psychological effects, and may provide an excellent alternative for stress reduction in women undergoing subfertility treatment (Luo et al., 1998; Chang et al., 2002; Middlekauff, 2004).

IVF is a well-established treatment for various causes of subfertility. It involves ovarian stimulation, which induces the development of multiple follicles, egg collection through the transvaginal route, and embryo transfer after fertilization. During transvaginal ultrasound-guided oocyte retrie-

Copyright - Todos os direitos reservados

SBRA - Sociedade Brasileira de Reprodução Assistida 
val, the needle passes through the vaginal wall to puncture the follicles in the ovary. The procedures are generally short, lasting about 20 to 30 minutes, but can still be painful without adequate anesthesia or analgesia. Other study showed that acupuncture had comparable analgesic effect as conventional analgesia. Similar results on the analgesic effect of acupuncture were subsequently reported by the same group (Stener-Victorin et al., 2003).

Acupuncture can be recommended as one of the effective analgesic methods for patients who are unable to comply with the conventional analgesia because of adverse effects during and after transvaginal ultrasound-guided oocyte retrieval (Sator-Katzenschlager et al., 2006).

Except for the study by Sator-Katzenschlager et al. (2006), other studies (Gejervall et al., 2005; Ng et al., 2008; So et al., 2009) failed to demonstrate any significant difference in the pregnancy rate between the acupuncture group and the control group receiving conscious sedation for pain relief Live birth rate was significantly higher in the acupuncture group than in the control group ( $\mathrm{Ng}$ et al., 2008).

The objective of this study was to evaluate IVF outcomes on patients undergoing acupuncture on the day of embryo transfer.

\section{METHODS \\ Study group}

A retrospective study was realized on a private Human Reproduction Center from March of 2010 to March of 2011 after approval by the UNINOVAFAPI Ethics Committee. Were included patients admitted for intracytoplasmic sperm injection (ICSI) and under acupuncture aiming for better infertility prognostic treatment.

A total of 30 patients realized acupuncture procedure. 21 realized acupuncture just on the day of embryo transfer, and 9 realized treatments with minimal 10 sections (from the initiation of treatment, on the day of transvaginal ultrasound-guided oocyte retrieval and on the day of embryo transfer). Due to all those patients undergone acupuncture on the embryo transfer day, the focus of the present study, they were put together at the same group. Others 108 patients of the same data collection period that didn't undergone acupuncture were determined as the control group.

Acupuncture group and control group were characterized for mean age, number cycles and infertility causes. The groups were similar, with no statistical significance difference able to deflect the results of data analyzes (Table 1 and 2).

\section{Acupuncture}

For systemic acupuncture some common points were used to address the specific problem of fertility, among them: CS3, Zigong, Bp4, R3, R6, bp6, E36, F2, F3, Vg4, $B 23$, Jing gong. In auricular acupuncture were Shenmen, Kidney, Liver, Spleen, Heart, Anxiety 1 and 2 (Cho et al.,

Table 1. Characterization of the groups.

\begin{tabular}{lcc}
\hline Features & $\begin{array}{c}\text { Acupuncture } \\
\text { group }\end{array}$ & $\begin{array}{c}\text { Control } \\
\text { group }\end{array}$ \\
\hline Mean age & $\mathrm{n}=30$ & $\mathrm{n}=108$ \\
\hline No. first ICSI cycle & 33.44 & 35.35 \\
\hline No. second ICSI cycle & 10 & 59 \\
\hline No. tertiary or more & 7 & 29 \\
ICSI cycle & 13 & 20 \\
\hline Causes of infertility (No.) & 3 & 20 \\
\hline Tubal & 8 & 28 \\
\hline Male & 5 & 20 \\
\hline Female & 9 & 23 \\
\hline Mixed & 5 & 17 \\
\hline Unexplained & &
\end{tabular}

Table 2. Characterization of oocytes and embryos.

\begin{tabular}{lcc|c}
\hline Features & $\begin{array}{c}\text { Acupuncture } \\
\text { group }\end{array}$ & $\begin{array}{c}\text { Control } \\
\text { group }\end{array}$ & p value* \\
\hline $\begin{array}{l}\text { No. oocytes } \\
\text { retrieval }\end{array}$ & 275 & 898 & \\
\hline $\begin{array}{l}\text { No. matured } \\
\text { oocytes (\%) }\end{array}$ & $256(93.09)$ & $\begin{array}{c}828 \\
(92.20)\end{array}$ & NS \\
\hline $\begin{array}{l}\text { No. normal } \\
\text { fertilized } \\
\text { oocytes (\%) }\end{array}$ & $154(74.75)$ & $\begin{array}{c}620 \\
(74.87)\end{array}$ & NS \\
\hline $\begin{array}{l}\text { No. embryos } \\
\text { cleaved (\%) }\end{array}$ & $153(99.35)$ & $\begin{array}{c}601 \\
(96.93)\end{array}$ & NS \\
\hline
\end{tabular}

*NS= Not significant

1998). It corroborates that in all patients were carried out a detailed medical history to diagnose the disorder energy of each alone. Although the treatment evolves different points, as Chinese medicine for the problem of infertility can come from various dysfunctions energy, and the acupuncturist must do a good diagnosis aiming a proper treatment. In the process systemic acupuncture were used needles, moxibustion (Arthemisia vulgaris), semi-permanent needles, micropore, scissors and tweezers, cotton and alcohol.

\section{Hyperstimulation and ICSI procedures}

Hormonal hyperstimulation used in all patients was long protocol (GnRH agonist) that started on day 21 of menstrual cycle, when serum estradiol concentrations were $<50 \mathrm{pg} /$ $\mathrm{ml}$ and follicular structures on ultrasound were $<8 \mathrm{~mm}$. The recombinant follicle stimulant hormone ( $\mathrm{rFSH})$ started according to the serum estradiol and ultrasound measurements of follicular diameter. When the follicle evaluate $>18 \mathrm{~mm}$ diameter, the ovulation was confirmed with human chorionic gonadotrophin (hCG) measurement.

Oocyte retrieval was performed 36 hours after hCG administration. Follicles were aspired with negative pressure, under transvaginal ultrasound guidance. ICSI was performed at 5 hours after retrieval, and embryo transferred back to the uterus on day 2 or 3 of culture. Luteal support was administrated by intravaginal progesterone (Vasconcelos et al., 2009). Pregnancy test was realized at 11-13 day after embryo transfer, by serum hCG in blood. At 21 day, clinical pregnancy was diagnosed by intrauterine gestational sac. Ongoing pregnancy was defined as the presence of viable intrauterine fetus beyond 12 weeks gestation.

\section{STATISTICAL ANALYSIS}

All statistical evaluation was performed using BioEstat 4.0. To compare the frequencies between two groups for fertilization, pregnancy rate, clinical pregnancy and ongoing pregnancy the $\mathrm{X} 2$ test was used, set at significant $\mathrm{p}<0.05$.

\section{RESULTS}

The group undergoing acupuncture presented more positive results, such as implantation and ongoing pregnancy; and presented lower negative results, such as early pregnancy loss. Although better clinical outcomes are found on the group undergoing acupuncture, no statistical significance was found to validate these findings (Table 3 ).

\section{DISCUSSION}

All positive clinical outcome percentage in acupuncture group were higher than in control group (Table 3), but these results did not present statistical significance, what does not prove the real efficacy of the acupuncture on IVF outcomes.

The positive effect of acupuncture during IVF treatment may be related to the change in uterine blood flow, uterine 
Table 3. Clinic outcomes of patients undergoing acupuncture on the day of embryo transfer.

\begin{tabular}{lccc}
\hline Features & Acupuncture & $\begin{array}{c}\text { Control } \\
\text { group }\end{array}$ & $\begin{array}{c}\text { p } \\
\text { value* }\end{array}$ \\
\hline $\begin{array}{l}\text { No. Cycle embryo } \\
\text { transferred }\end{array}$ & 30 & 108 & NS \\
\hline $\begin{array}{l}\text { No. Embryo } \\
\text { Etransferred }\end{array}$ & 81 & 326 & NS \\
\hline $\begin{array}{l}\text { Positive pregnancy } \\
\text { test per cycle (\%) }\end{array}$ & $15(50.0)$ & $\begin{array}{c}38 \\
(35.18)\end{array}$ & NS \\
\hline $\begin{array}{l}\text { Clinical pregnancy } \\
\text { rate (\%) }\end{array}$ & $15(50.0)$ & $\begin{array}{c}37 \\
(34.25)\end{array}$ & NS \\
\hline $\begin{array}{l}\text { Early pregnancy } \\
\text { loss (\%) }\end{array}$ & $1(6.66)$ & $\begin{array}{c}6 \\
(15.78)\end{array}$ & NS \\
\hline $\begin{array}{l}\text { Ongoing pregnancy } \\
(\%)\end{array}$ & $14(46.66)$ & $\begin{array}{c}32 \\
(29.62)\end{array}$ & NS \\
\hline $\begin{array}{l}\text { Implantation rate } \\
(\%)\end{array}$ & $16(19.75)$ & $\begin{array}{c}51 \\
(15.64)\end{array}$ & NS \\
\hline
\end{tabular}

*NS= Not significant

contractility and relaxation of stress. Sator-Katzenschlager et al. (2006) realized that the improvement of pregnancy rate was related to the administration of acupuncture on the day of embryo transfer but no improvement of pregnancy rate was observed when acupuncture were administrated on the day of transvaginal ultrasound-guided oocyte retrieval only. These results suggest that acupuncture may only improve pregnancy rate when administered on the day of embryo transfer.

$\mathrm{Ng}$ et al. (2008) related no difference among groups that undergone acupuncture treatment session and placebo group before embryo transfer. In fact, the placebo group showed higher pregnancy rate. So et al. (2009) obtained similar results, although they found significant changes in endometrial and subendometrial vascularity, serum cortisol concentration and the anxiety level were documented following both real and placebo acupuncture.

There are several hypotheses to explain acupuncture action, but the exact underlying biological mechanism of acupuncture is difficult to explain. Acupuncture might cause placebo effect (Amanzio \& Benedetti, 1999; Birch, 2006) but, even considering this possibility, the present study did not verified statistical significance difference among the groups.

Pinborg et al. (2008) relate an enhancement in the success of IVF using acupuncture higher than for drugs or other procedures, but the methodology of this studied is questioned, due to the difficulty to blind the studies in acupuncture. Acupuncture may change the blood flow into uterus and prepare a more suitable environment to embryo implantation, but there are not sufficient numbers of randomized and double blinded studies to validate this. Evidence supporting the role of acupuncture in male subfertility is also insufficient, because most of the studies are uncontrolled case reports or case series in which the sample sizes were small. Due to that lack in the methodology, more double blinded studies with bigger sample sizes are necessary to confirm real influence of acupuncture in IVF (Stener-Victorin et al., 1999; So et al., 2009).

Even if the effects of acupuncture on the outcome of IVF cannot be confirmed, it might still be useful as an alternative or tool for pain relief (Humaidan \& Stener-Victorin, 2004) during transvaginal ultrasound-guided oocyte retrieval in patients who cannot tolerate the conventional conscious sedation because of its associated adverse effects.

\section{CONCLUSION}

The present study could not demonstrate positive or negative influence of the acupuncture with statistical significance onto the outcome of IVF treatment.

\section{CONFLICT OF INTEREST}

The authors report no conflict of interest.

Autor correspondente

Bráulio Fernandes de Carvalho

Telefone: +81 08031708546 (Japão)

Email: hazbio@gmail.com

\section{Correspondência}

CARVALHO, Bráulio Fernandes de

Stem Cell Differentiation Research Team, Research Center for Stem Cell Engineering, National Institute for Advanced Industrial Science and Technology AIST Tsukuba Central $4-1-3106$

Higashi 1-1-1, Tsukuba, Ibaraki, Japan 305-8562

\section{Local de desenvolvimento da pesquisa}

UNINOVAFAPI, Rua Vitorino Orthiges Fernandes, 6123 Bairro Uruguai I CEP: 64073-505, Teresina - Piauí Fone: (86) 2106-0700 / Fax: (86) 2106-0740.

Observação: Os autores declaram ausência de conflito de interesses e inexistência de financiamento externo ou recebimento de auxílios para a execução da pesquisa.

\section{REFERENCES}

Amanzio M, Benedetti F. Neuropharmacological dissection of placebo analgesia: expectation-activated opioid systems versus conditioning activated specific subsystems. J Neurosci. 1999; 19:484-494. Andresson S, Lundeberg T. Acupuncture from empiricism to science functional background to acupuncture effects in pain and disease. Med Hypoth. 1995; 45:271-81.

Birch S. A review and analysis of placebo treatments, placebo effects, and placebo controls in trials of medical procedures when sham is not inert. J Altern Complement Med. 2006; 12:303-310

Chang $\mathrm{R}$, Chung $\mathrm{PH}$, Rosenwaks Z. Role of acupuncture in the treatment of female fertility. Fertil Steril. 2002; 78:1149-53.

Chen BY, Yu J. Relationship between blood radioimmunoreactive beta-endorphin and hand skin temperature during the electro-acupuncture induction of ovulation. Acupunct Electrother Res. 1991; 16:1-5.

Cho $\mathrm{ZH}$, Chung SC, Jones JP, Park JB, Park HJ, Lee $\mathrm{HJ}$ et al. New finding of the correlation between acupoints and corresponding brain cortices using functional MRI. Proc Natl Acad Sci USA. $1998 ; 3: 2670-3$

Fanchin R, Righini C, Olivennes F, Taylor S, Ziegler D, Frydman $R$. Uterine contractions at the time of embryo transfer alter pregnancy rates after in-vitro fertilization. Hum Reprod. 1998; 13:1968-74.

Ferin M, Wiele V. Endogenous opioid peptides and the control and the control of the menstrual cycle. Eur J Obstet Reprod Biol. $1984 ; 18: 365-73$.

Gejervall AL, Stener-Victorin E, Moller A, Janson PO, Werner $C$, Bergh C. Electro-acupuncture versus conventional analgesia: a comparison of pain levels during oocyte aspiration and patient's experiences of well-being after surgery. Hum Reprod. 2005 20:728-35.

Ghoname ES, Craig WF, White PF, Ahmed HE, Hamza MA, Gajraj NM et al. The effect of stimulus frequency on the analgesic response to percutaneous electrical nerve stimulation in patients with chronic low back pain. Anesth Analg. 1999; 88:841-6.

Han JS. Acupuncture: neuropeptides release produced by electrical stimulation of different frequencies. Trends Neurosci. 2003; 26:17-22.

Humaidan $P$, Stener-Victorin E. Pain relief during oocyte retrieval with a new short duration electro-acupuncture technique as an alternative to conventional analgesic methods. Hum Reprod. 2004; 19:1367-72.

Kim J, Shin KH, Na SC. Effect of acupuncture treatment on uterine motility and cyclooxygenase-2 expression in pregnant rats. Gynecol Obstet Invest. 2000; 50:225-30.

$\mathrm{Ku}$ Y, Chang Y. Beta-endorphin and GABA-mediated depressor effect of specific electroacupuncture surpasses pressor response of emotional circuit. Peptides. 2001; 22:1465-70. 
Luo H, Meng F, Jia Y, Zhao X. Clinical research on the therapeutic effect of the electroacupuncture treatment in the patients with depression. Clin Neusosi. 1998; 52:338-40.

Middlekauff HR. Acupuncture in the treatment of heart failure. Cardiol Rev. 2004; 12:171-3.

$\mathrm{Ng}$ EHY, So WZ, Gao J, Wong YY, Ho PC. The role of acupuncture in the management of subfertility. Fertil Steril 2008; 90:1-13.

Petraglia F, Di Meo G, Storchi R, Segre A, Facchinetti F, Szalay S et al. Proopiomelanocotin-related peptides and methionin enkephalin in human follicular fluid: changes during the menstrual cycle. Am J Obstet Gynecol. 1987; 157:142-6.

Pettie F, Bangrazi A, Liguori A, Reale G, Ippoliti F. Effects of acupuncture on immune response related to opioids-like peptides. J Tradit Chin Med. 1998 ; 18:55-63

Pinborg A, Loft A, Andersen AN. Acupuncture with in vitro fertilization. BMJ. 2008; 336:517-518.

Sato A, Sato Y, Schmidt RF. The impact of somatosensory input on autonomic functions. Heidelberg: Springer-Verlag. 1997; 325.

Sator-Katzenschlager SM, Wolfer MM, Kozek-Langenecker SA, Sator K, Sator PG, Li1 B. Auricular electro-acupuncture as an additional perioperative analgesic method during oocyte aspiration in IVF treatment. Hum Reprod. 2006; 21:2114-20.

So EWS, Ng EHY, Wong YY, Lau EYL, Yeung WSB, Ho PC. A randomized double blind comparison of real and placebo acupuncture in IVF treatment. Hum Reprod. 2009; 24(2):341-348.

Stener-Victorin E, Waldenstrom U, Andersson SA, Wikland M Reduction of blood flow impedance in the uterine arteries of infertile women with electro-acupuncture. Hum Reprod. 1996; $11: 1314-7$.
Stener-Victorin E, Waldenstrom U, Nilsson L, Wikland, Janson PO. A prospective randomized study of electro-acupuncture versus alfentanil as anaesthesia during oocyte aspiration in in-vitro fertilization. Hum Reprod. 1999; 14, 2480-4.

Stener-Victorin E, Waldenstrom U, Wikland M, Nilsson L, Hägglund L, Lundeberg T. Electro-acupuncture as a preoperative analgesic method and its effects on implantation rate and neuropeptide $Y$ concentrations in follicular fluid. Hum Reprod. 2003; 18:1454-60.

Tang NM, Dong HW, Wang XM, Tsui ZC, Han JS. Cholecystokinin antisense RNA increases the effect induced by electroacupuncture or low dose morphine: conversion of low responder rats into high responders. Pain. 1997; 71:71-80.

Vasconcelos PAS, Sene IS, Sousa GNS, Carvalho BF, Costa ALE. Correlation of transferency day and embryos quality with pregnancy rate. JBRA Assist Reprod. 2009; 13(1):21-24.

Westergaard LG, Mao Q, Krogslund M, Sandrini S, Lenz S, Grinsted J. Acupuncture on the day of embryo transfer significantly improves the reproductive outcome in infertile women: a prospective, randomized trial. Fertil Steril. 2006; 85:1341-6.

White PF, Craig WF, Vakharia AS, Ghoname E, Ahmed HE, Hamza MA. Percutaneous neuromodulation therapy: does the location of electrical stimulation effect the acute analgesic response? Anesth Analg. 2000; 91:949-54.

Zhang WT, Jin Z, Cui GH, Zhang KL, Zhang L, Zeng YW et al. Relations between brain network activation and analgesic induced by low vs high frequency electrical acupoint stimulation in different subjects: a functional magnetic resonance imaging study. Bran Res. 2003; 29:168-78. 